\title{
Recombinant Human Granulocyte-Macrophage Colony-stimulating Factor Stimulates In Vitro Mature Human Neutrophil and Eosinophil Function, Surface Receptor Expression, and Survival
}

Angel F. Lopez, D. James Williamson, Jennifer R. Gamble, C. Glenn Begley, John M. Harlan, Seymour J. Klebanoff, Ann Waltersdorph, Gordon Wong, Steven C. Clark, and Mathew A. Vadas

Walter and Eliza Hall Institute of Medical Research, PO Royal Melbourne Hospital, Victoria 3050, Australia; Division of Human Immunology, Institute of Medical \& Veterinary Science, Adelaide 5000, South Australia; Department of Medicine, University of Washington, Seattle, Washington 98195; and Genetics Institute, Boston, Massachusetts 02115

\begin{abstract}
A purified recombinant human granulocyte-macrophage colony stimulating factor (rH GM-CSF) was a powerful stimulator of mature human eosinophils and neutrophils. The purified rH GMCSF enhanced the cytotoxic activity of neutrophils and eosinophils against antibody-coated targets, stimulated phagocytosis of serum-opsonized yeast by both cell types in a dose-dependent manner, and stimulated neutrophil-mediated iodination in the presence of zymosan. In addition, $\mathbf{r H}$ GM-CSF enhanced $\boldsymbol{N}$ formylmethionylleucylphenylalanine(FMLP)-stimulated degranulation of Cytochalasin B pretreated neutrophils and FMLPstimulated superoxide production. In contrast, rH GM-CSF did not promote adherence of granulocytes to endothelial cells or plastic surfaces. rH GM-CSF selectively enhanced the surface expression of granulocyte functional antigens 1 and 2 , and the Mo1 antigen. rH GM-CSF induced morphological changes and enhanced the survival of both neutrophils and eosinophils by 6 and $9 \mathrm{~h}$, respectively. These experiments show that granulocytemacrophage colony stimulating factor can selectively stimulate mature granulocyte function.
\end{abstract}

\section{Introduction}

Colony stimulating factors (CSF) ${ }^{1}$ are a group of cell-derived products responsible for the proliferation and differentiation of progenitor cells (1). Recent evidence also suggests that CSF functionally activate mature cells, a process that takes place in a lineage-specific fashion (2-4). In humans, naturally occurring CSF have been only partially purified biochemically (5-7); however, their first definitive identification has been recently achieved by recombinant DNA technology $(8,9)$.

Address correspondence and reprint requests to Dr. Lopez, Div. of $\mathrm{Hu}-$ man Immunology, Institute of Medical \& Veterinary Science, Box 14, Rundle Mall Post Office, Adelaide 5000, South Australia. 1986

Received for publication 18 March 1986 and in revised form 6 June

1. Abbreviations used in this paper: ADCC, antibody-dependent cellmediated cytotoxicity; CR3, complement receptor type 3 for the C3bi portion of C3; CSF, colony-stimulating factor; FACS, fluorescence-activated cell sorter; FCS, fetal calf serum; FITC, fluorescein-isothiocyanate; FMLP, $N$-formylmethionylleucylphenylalanine; GFA, granulocytefunctional antigen; G, granulocyte; GM, granulocyte-macrophage; HPCM, human placental conditioned medium; LPS, lipopolysaccharide; MAb, monoclonal antibodies; M, macrophage; PMA, phorbol-myristate acetate; rH GM-CSF, recombinant human granulocyte-macrophage colony-stimulating factor.

J. Clin. Invest.

(c) The American Society for Clinical Investigation, Inc.

$0021-9738 / 86 / 11 / 1220 / 09 \quad \$ 1.00$

Volume 78, November 1986, 1220-1228
One of these recombinant human granulocyte-macrophage CSF (rH GM-CSF) was cloned from a complementary DNA library prepared from Mo cell messenger RNA and was found to stimulate in cultures of human bone marrow the formation of granulocyte-macrophage (GM) and eosinophil (Eo) colonies $(4,8)$, exhibiting all the functions of the previously described CSF- $\alpha$ obtained from human placenta (6). In all assays used, this was different from CSF- $\beta$ that has no effect on eosinophil proliferation (6) and from a human-active murine eosinophilCSF that has no effect on neutrophil progenitor cells (10). In this paper we definitively show that this rH GM-CSF activates mature human neutrophils as well as eosinophils and that this stimulation is selective as $\mathrm{rH} \mathrm{GM-CSF}$ does not enhance the adherence of these cells to endothelium or plastic surfaces. In addition, we show that activation is associated with an increase in the expression of certain surface antigens associated with function and with a significant prolongation of cell survival.

\section{Methods}

\section{Purification of human neutrophils and eosinophils}

These cells were obtained from the peripheral blood of healthy volunteers after dextran sedimentation and centrifugation on a gradient of hypertonic Metrizamide (Nyegaard, A/C, Oslo) as previously described (11). The purity was $>95 \%$ for neutrophils and $>92 \%$ for eosinophils. The cells were resuspended in Eagle's minimal essential medium supplemented with $10 \%$ fetal calf serum (FCS), $20 \mathrm{mM}$ Hepes buffer, and antibiotics. In experiments involving polarization, iodination, and adherence, blood was collected by using $0.2 \%$ ethylenediaminetetraacetic acid as anticoagulant. The neutrophils were isolated by density gradient centrifugation in Hypaque-Ficoll, sedimentation in dextran, and hypotonic lysis of erythrocytes as previously described (12). The preparation, which always contained $>97 \%$ neutrophils with an average purity of $98-99 \%$, was suspended in $0.9 \%$ sodium chloride at $5 \times 10^{7}$ neutrophils per milliliter.

\section{rH GM-CSF, conditioned media containing CSF, and recombinant human tumor necrosis factor $\alpha$ ( $r H T N F \alpha)$}

rH GM-CSF was obtained from the supernatant of COS cells that had been transfected with cloned human GM-CSF cDNA in the p91203 (B) vector as described (8) and incubated in serum-free medium for $4 \mathrm{~d}$. The supernatant was concentrated by ultrafiltration and the GM-CSF was purified to homogeneity as described (8). Silver-staining of the sodium dodecyl sulfate-polyacrylamide gel electrophoresis of the purified GMCSF revealed a major band of 19,000 molecular weight. The specific activity of this $\mathrm{rH}$ GM-CSF was $40 \mathrm{U} / \mathrm{ng}$ of protein. This material contained $<0.2 \mathrm{ng} / \mathrm{ml}$ of endotoxin as determined by a limulus amoebocyte lysate assay. CSF- $\alpha$ and CSF- $\beta$. were obtained after fractionation of medium conditioned by the human bladder cell carcinoma line U5637 by phenyl-sepharose chromatography (13), and were a gift from Dr. N. A. Nicola (Walter and Eliza Hall Institute, Melbourne, Australia). rH TNF $\alpha$ was a gift from Genentech, Inc., South San Francisco, CA and contained $3.6 \times 10^{7} \mathrm{U} / \mathrm{mg}$, as assayed (by the supplier) for its cytotoxic activity on actinomycin D-treated L929 mouse fibroblast cells. rH TNF $\alpha$ was produced in Escherichia coli (14) and purified to $99.8 \%$ purity. This material 
contained $0.8 \mathrm{ng} / \mathrm{ml}$ endotoxin as determined by a limulus amoebocyte lysate assay.

\section{Antibody-dependent cell-mediated cytotoxicity assay (ADCC)}

ADCC was performed as previously described (2). In brief, $40 \mu \mathrm{l}$ of ${ }^{51} \mathrm{Cr}$ labeled, trinitrophenyl (TNP)-coupled P815 cells $\left(4 \times 10^{3}\right)$ were incubated with $24 \mu \mathrm{l}$ of rabbit IgG anti-TNP (Miles-Yeda, Rehovot, Israel), $80 \mu \mathrm{l}$ of purified human neutrophils or eosinophils $\left(1.3 \times 10^{5}\right)$ as effector cells, and $16 \mu \mathrm{l}$ of rH GM-CSF for $2 \mathrm{~h}$ at $37^{\circ} \mathrm{C}$ in V-bottom microtiter plates. Percent cytotoxicity was calculated from the formula: (test - control/ total - control) $\times 100$, where "control" was the ${ }^{51} \mathrm{Cr}$ released by $\mathrm{P} 815$ cells in the presence of medium alone, and "total" was the ${ }^{51} \mathrm{Cr}$ released by the addition of $5 \%$ Triton X-100.

\section{Phagocytosis assay}

This assay measured the phagocytosis of serum-opsonized baker's yeast and was performed as described (15) and modified (4). In brief, $100 \mu \mathrm{l}$ purified neutrophils $\left(2 \times 10^{7} / \mathrm{ml}\right)$ were incubated with $250 \mu$ l baker's yeast, $100 \mu \mathrm{l}$ diluted fresh autologous serum, and $50 \mu \mathrm{l} \mathrm{rH}$ GM-CSF or medium with $\mathrm{FCS}$ for $1 \mathrm{~h}$ at $37^{\circ} \mathrm{C}$. After this, the cells were centrifuged at $4^{\circ} \mathrm{C}$, resuspended in $50 \mu \mathrm{l}$ of cold phosphate-buffered saline (PBS), and smeared onto a slide. When eosinophils were tested, this assay was scaled down because of the relatively low numbers of eosinophils routinely obtained. The volumes were $20 \mu \mathrm{l}$ of cells $\left(10^{7} / \mathrm{ml}\right), 50 \mu \mathrm{l}$ of baker's yeast, $20 \mu \mathrm{l}$ of freshly obtained human serum, and $10 \mu \mathrm{l}$ of $\mathrm{rH}$ GM-CSF or medium. After incubation, cytocentrifuge preparations were made. Slides were fixed in methanol and stained with Giemsa before being examined for the number of cells showing different numbers of phagocytosed yeast. The data are expressed as percentages after counting a minimum of 200 cells per slide.

\section{Degranulation assay}

This was carried out as previously described (16). Briefly, purified neutrophils $\left(5 \times 10^{6} / \mathrm{ml}\right)$ pretreated with cytochalasin B (Sigma Chemical Co., St. Louis, MO) for $15 \mathrm{~min}$ at $37^{\circ} \mathrm{C}$ were incubated with different stimuli for $15 \mathrm{~min}$ at $37^{\circ} \mathrm{C}$. To these mixtures different concentrations of FMLP (Sigma Chemical Co.) were added and the cells incubated a further $30 \mathrm{~min}$ at $37^{\circ} \mathrm{C}$. After incubation the cells were centrifuged and the released lysozyme was assayed against Micrococcus lysodeikticus (Sigma). The O.D. at $450 \mathrm{~nm}$ was measured in triplicate at $10 \mathrm{sec}$. intervals for $3 \mathrm{~min}$. and the amount of lysozyme released was calculated from a standard curve generated by egg white lysozyme (Sigma Chemical Co.). Maximum values were obtained by using supernatants from neutrophils lysed with Triton X-100.

\section{Iodination}

Iodination was measured by the conversion of radioiodide to a trichloroacetic acid (TCA)-precipitable form as previously described (17). Zymosan (ICN Pharmaceuticals, Inc., Cleveland, $\mathrm{OH}$ ) was prepared by homogenization in water, after which it was boiled for $20 \mathrm{~min}$, washed twice, and suspended in water at $10 \mathrm{mg} / \mathrm{ml}$. The reaction mixture contained $4 \times 10^{-3} \mathrm{M}$ sodium phosphate buffer, $\mathrm{pH} 7.4,0.128 \mathrm{M} \mathrm{NaCl}, 1.2$ $\times 10^{-2} \mathrm{M} \mathrm{KCl}, 10^{-3} \mathrm{M} \mathrm{CaCl}_{2}, 2 \times 10^{-3} \mathrm{M} \mathrm{MgCl}_{2}, 8 \times 10^{-6} \mathrm{M} \mathrm{Na} \mathrm{I}(4$ $\left.\mathrm{nmol} ; 0.05 \mathrm{Ci}^{125} \mathrm{I}\right), 2 \times 10^{-3} \mathrm{M}$ glucose, $0.25 \mathrm{mg}$ albumin, $2.5 \times 10^{6}$ neutrophils, and where indicated, $2 \mathrm{ng} / \mathrm{ml} \mathrm{rH}$ GM-CSF, $0.5 \mathrm{mg}$ zymosan, or both. The components of the reaction mixture were incubated for 60 min at $37^{\circ} \mathrm{C}$ in $12 \times 75$-mm polystyrene test tubes on a Rotor-Rack (Fisher Scientific Co., Pittsburgh, PA) and the reaction was stopped by the addition of $1 \mathrm{ml}$ of cold $10 \%$ TCA. The precipitate was collected by centrifugation at $2,500 \mathrm{~g}$ for $5 \mathrm{~min}$ in a refrigerated centrifuge, washed four times with $2 \mathrm{ml}$ of $10 \%$ TCA, and the counts per minute were determined in a gamma scintillation counter. A blank containing the standard salt solution, iodine and albumin, was run with each experiment and the results were subtracted from the experimental values. $<0.05 \%$ of the total added radioiodide was TCA-precipitable in the blank. A standard containing the total ${ }^{125} \mathrm{I}$ added to each experimental tube was counted and the percent iodination was determined as follows: (cpm experimental $-\mathrm{cpm}$ blank $\times 100) /(\mathrm{cpm}$ standard). The results are expressed as nanomoles of iodide converted to a TCA-precipitable form per $10^{7} \mathrm{PMN}$ per hour or percent iodide converted to a TCA-precipitable form. Each experimental value was determined in duplicate and averaged for statistical analysis of stated number of experiments.

\section{Superoxide production}

Purified neutrophils were incubated with medium or different concentrations of rH GM-CSF for $2 \mathrm{~h}$ at $37^{\circ} \mathrm{C}$. After this, $150 \mu \mathrm{l}$ of cells $\left(10^{6}\right)$ were mixed with $100 \mu \mathrm{l}$ freshly prepared cytochrome-c (Sigma Chemical Co., type VI, $12.4 \mathrm{mg} / \mathrm{ml}), 100 \mu \mathrm{l} \mathrm{FMLP}\left(10^{-6} \mathrm{M}\right)$, and made up to 1 $\mathrm{ml}$ with medium. The mixtures were then incubated at $37^{\circ} \mathrm{C}$ for $5 \mathrm{~min}$, after which the cells were rapidly cooled, centrifuged at $4^{\circ} \mathrm{C}$, and the supernatants were transferred to plastic disposable cuvettes. Superoxide production was measured by the reduction of cytochrome-c (18) using an extinction coefficient of $21.1 \mathrm{mM}^{-1}$ (19).

The medium used throughout these assays was RPMI (free of phenol red) containing $2 \%$ FCS. In control experiments, rH GM-CSF did not reduce cytochrome- $c$ in the absence of cells, and superoxide dismutase (Sigma Chemical Co.) completely abolished the reduction of cytochrome$c$. The results are expressed as the means of triplicate determinations \pm 1 SD.

\section{Neutrophil adherence assays}

These assays measured the adherence of neutrophils to human endothelial cells and to plastic. Neutrophils were first radiolabelled with ${ }^{51} \mathrm{Cr}$ by the method of Gallin et al. (20). Briefly, neutrophils were suspended in Hank's balanced salt solution (HBSS) (Gibco, Grand Island, NY) with $1 \mathrm{mM}$ calcium, $2 \mathrm{mM}$ magnesium, and $0.1 \%$ gelatin at $24 \times 10^{6} / \mathrm{ml}$ and incubated with $24 \mathrm{Ci} / \mathrm{ml}^{51} \mathrm{Cr}$ (as sodium chromate, $200-500 \mathrm{Ci} / \mathrm{g}$, New England Nuclear, Boston, MA) at $37^{\circ} \mathrm{C}$ for $1 \mathrm{~h}$ with periodic gentle agitation. After incubation, free ${ }^{51} \mathrm{Cr}$ was removed by washing twice with HBSS. Labeled neutrophils were resuspended in RPMI 1640 medium (MA Bioproducts, Walkersville, MD) or in RPMI 1640 medium with $5 \%$ FCS at a final concentration of $10^{6} / \mathrm{ml}$.

Adherence to endothelial cells. Endothelial cells were isolated by collagenase treatment of human umbilical cord veins and were maintained in endotoxin-free RPMI 1640 medium with 10\% FCS as previously described (21). In the adherence assay, human endothelial cells were plated in RPMI 1640 medium with 20\% FCS in 16-mm-diam wells (Costar, Cambridge, MA) at $10^{5}$ cells $/ \mathrm{cm}^{2}$ and grown to confluence. Prior to assay, the medium was decanted and the endothelial cell monolayers were washed once with RPMI 1640 medium containing 5\% FCS. To each well, a total volume of $250 \mu \mathrm{l}$ was added, containing $5 \times 10^{551} \mathrm{Cr}$ labeled neutrophils and the test substance. The mixture was then gently agitated and the cells were incubated with the endothelial cell monolayers at $37^{\circ} \mathrm{C}$ with $5 \% \mathrm{CO}_{2}$. After a 30 -min incubation, the supernatant medium and the nonadherent ${ }^{51} \mathrm{Cr}$-labeled neutrophils were aspirated and each well was washed once with RPMI 1640 medium containing 5\% FCS. Aspirated nonadherent neutrophils, incubation medium, and the wash medium from each well were pooled in individual counting tubes and were counted in a gamma spectrophotometer. The endothelial cell monolayers and the adherent ${ }^{51} \mathrm{Cr}$-labeled neutrophils were then lysed for at least $2 \mathrm{~h}$ with $1 \mathrm{M} \mathrm{NH}_{4} \mathrm{OH}$. The $\mathrm{NH}_{4} \mathrm{OH}$ lysate and wash from each well were counted in a gamma spectrophotometer. Adherence was determined as the percent of the total ${ }^{51} \mathrm{Cr}-\mathrm{cpm}$ added: percent adherence $=\left({ }^{51} \mathrm{Cr}-\mathrm{cpm}\right.$ in adherent neutrophils $) /\left(\right.$ Total ${ }^{51} \mathrm{Cr}$-cpm added $) \times 100$. Total ${ }^{51} \mathrm{Cr}$-cpm added was calculated for each well as the sum of ${ }^{51} \mathrm{Cr}$ cpm in supernatant medium, washes, and lysate. Total ${ }^{51} \mathrm{Cr}-\mathrm{cpm}$ varied between wells by $<10 \%$.

Adherence to plastic. $100 \mu \mathrm{l}$ of ${ }^{51} \mathrm{Cr}$-labeled neutrophils $\left(5 \times 10^{3}\right)$ in HBSS containing $0.5 \%$ bovine serum albumin were added to roundbottom polyvinylchloride microtiter plates together with $5 \mu l$ of stimulus and incubated at $37^{\circ} \mathrm{C}$. After this, the nonadherent cells were removed as above and adhered and nonadherent cells counted in a gamma counter. Adherence was calculated as above. In each case quadruplicate determinations were made.

\section{Immunofluorescence assay}

This was carried out as previously described (22). Briefly, purified neutrophils $\left(10^{7} / \mathrm{ml}\right)$ were incubated with medium or $2 \mathrm{ng} / \mathrm{ml}$ of $\mathrm{rH} \mathrm{GM-}$ 
$\mathrm{CSF}$ for $1 \mathrm{~h}$ at $37^{\circ} \mathrm{C}$ after which they were washed three times and mixed with monoclonal antibodies (MAb) directly conjugated with fluorescein isothiocyanate (FITC) (23). The mouse MAb used were WEM-G1, an IgM directed against granulocyte-functional antigen (GFA)-1 (24), WEMG11 F(ab') 2 directed against GFA-2 (15), Mo1-FITC (Coulter Electronics, Inc., Hialeah, FL), an IgM directed against the Mo-1/OKM1 antigen $(25,26)$ in the $C D_{11}$ cluster, anti- $\beta_{2}$ microglobulin (an IgG2b anti- $\beta_{2} \mathrm{~m}$, gift from Dr. I. F. C. Mackenzie), K? (IgM anti-TNP), and PB10 (an IgGl against the chicken theta antigen, gift from Dr. P. Bartlett, The Walter and Eliza Hall Institute.) The incubation was carried out in microtiter plates for $45 \mathrm{~min}$ at $4^{\circ} \mathrm{C}$. After being washed three times the cells were fixed before analysis by flow cytometry as described (22).

\section{Polarization}

Changes in cell shape of neutrophils accompanying activation have been described previously (27) and involve an elongation and assumption of irregular shape by the cell. Granulocytes were incubated with rH GM$\mathrm{CSF}$ or medium at $37^{\circ} \mathrm{C}$ in a $100-\mu \mathrm{l}$ volume in conical polypropylene tubes. After incubation, the cells were fixed as previously described (22) and duplicate samples of more than 100 cells were examined in a cellcounting chamber. These changes were accompanied by an increase in the flow cytometric parameter of forward or $0^{\circ}$ light scatter (28) which were measured in a flow microfluoremeter (Ortho cytofluorograph) and are expressed as the mean of 15,000 cells. Besides the magnitude of the $0^{\circ}$ scatter signal, the pulse width of this signal was also significantly increased.

In eosinophils, a shape change was also observed. The cells assumed a triangular shape with the granules clearly concentrated toward the base. The appearance was strikingly similar to candy corn.

\section{Granulocyte survival assay}

Details of this assay are described elsewhere (Begley, C. G., A. F. Lopez, N. A. Nicola, D. J. Warren, C. J. Sanderson, and M. A. Vadas, manuscript submitted for publication). In brief, purified neutrophils and eosinophils were placed in Terasaki wells and cultured in the presence of serial twofold dilutions of $\mathrm{rH}$ GM-CSF in medium containing 10\% FCS. After regular intervals, the cells were examined by phase contrast and eosin exclusion, and the number of viable cells was recorded. The data are expressed as mean viable cells from duplicate wells.

\section{Statistical analysis}

The $P$ values given were derived after comparing the values obtained with cells from the same individual before and after stimulation with CSF by the Student's method of paired differences unless stated otherwise.

\section{Results}

Effect of $r H$ GM-CSF on ADCC by human neutrophils and eosinophils. rH GM-CSF was found to stimulate the ADCC of tumor cells by both neutrophils and eosinophils. A typical titration curve with neutrophils and eosinophils purified from the same individual showed (Fig. 1) that rH GM-CSF was active on both cell types over a wide range of concentrations. Eosinophils consistently responded to a greater degree than neutrophils. In other experiments $\mathrm{rH}$ GM-CSF increased the percentage of ADCC by eosinophils from $5.8 \%$ to $48.6 \%$ (mean of four experiments, $P<0.0001$ ) and in the case of neutrophils, from $12.5 \%$ to $31.5 \%$ (mean of four experiments, $P<0.001$ ). In the presence of lipopolysaccharide (LPS) at $1 \mathrm{ng} / \mathrm{ml}$ the percentage ADCC by neutrophils was $12.8 \%$ (mean of two experiments, not significant). The cytotoxicity observed was not due to toxic effects of rH GM-CSF since this material did not induce killing of P815 cells in the absence of either granulocytes or anti-TNP antibody (data not shown).

Effect of rH GM-CSF on neutrophil and eosinophil-mediated phagocytosis. Fig. 2 shows one representative experiment out of

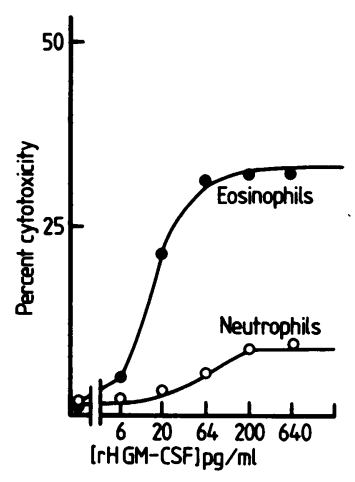

Figure 1. Stimulation by rH GM-CSF of the ADCC of tumor cells by human neutrophils (open circles) and eosinophils (closed circles) from the same individual. Dose-response. Each point is the mean of triplicate determinations.

four performed in which neutrophils phagocytosed baker's yeast in the presence of different concentrations of normal human serum. Very little phagocytic activity was observed in the absence of serum. The addition of $2 \mathrm{ng} / \mathrm{ml}$ of $\mathrm{rH} \mathrm{GM}-\mathrm{CSF}$ resulted in an increase in neutrophil-mediated phagocytosis of baker's yeast at serum concentrations of $2.5 \%$ and $1.25 \%$ (Fig. 2) but not 5\%, a concentration that appeared to saturate this system. This stimulatory effect of rH GM-CSF was seen both in terms of the number of neutrophils showing phagocytosis and in the number of ingested yeast per neutrophil.

In order to establish the concentration of rH GM-CSF necessary to stimulate neutrophil-mediated phagocytosis, a titration of rH GM-CSF was carried out using $1.2 \%$ serum. In one experiment that was representative of three performed, rH-CSF stimulated phagocytosis by neutrophils at 2 and $0.2 \mathrm{ng} / \mathrm{ml}$, but was ineffective at $0.02 \mathrm{ng} / \mathrm{ml}$ (Fig. 3).

To test whether this rH GM-CSF was also able to stimulate phagocytosis of serum-opsonized baker's yeast by mature eosinophils, $\mathrm{rH}$ GM-CSF was used at $2 \mathrm{ng} / \mathrm{ml}$ over a range of serum concentrations. In two experiments performed, rH GM-CSF activated eosinophil-mediated phagocytosis when baker's yeasts were opsonized with $2.5 \%$ or $1.2 \%$ human serum. One of these experiments is illustrated in Fig. 4. Similar to its effect on neutrophils, rH GM-CSF increased both the number of eosinophils showing phagocytosis, and the number of ingested yeasts per eosinophil. No stimulation was seen if human serum was omitted or heat-inactivated at $56^{\circ} \mathrm{C}$ for $40 \mathrm{~min}$. LPS at a concentration between 0.1 and $1 \mathrm{ng} / \mathrm{ml}$ (at least 10 times higher than that present in rH GM-CSF) was found not to have an effect in this system (data not shown).

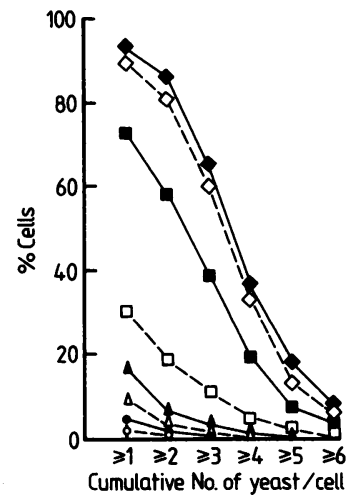

Figure 2. Stimulation by $\mathrm{rH}$ GM-CSF of neutrophil-mediated phagocytosis of yeast organisms opsonized with different concentrations of fresh human serum. Closed symbols show the values obtained in the presence of $2 \mathrm{ng} /$ $\mathrm{ml}$ of $\mathrm{rH} \mathrm{GM}$-CSF and open symbols show those obtained in the presence of medium at serum concentrations of $5 \%(\diamond), 2.5 \%(\square), 1.25 \%(\Delta)$, and none (o). Each point is the mean of triplicate determinations. The values obtained with neutrophils treated with rH GM-CSF were significantly different from those obtained with neutrophils treated with medium by $\chi^{2}$ analysis $(P<0.001)$ at a $2.5 \%$ serum concentration. 


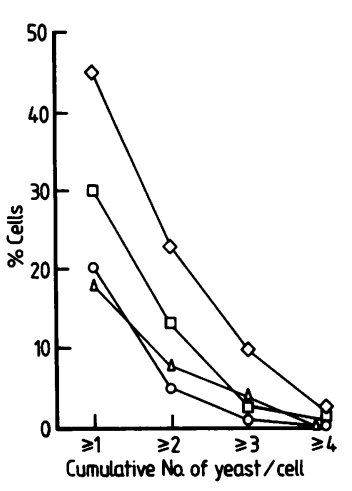

Figure 3. Stimulation by rH GM-CSF of neutrophil-mediated phagocytosis of yeast organisms opsonized with $1.25 \%$ human serum: dose response. The concentrations of $\mathrm{rH}$ GM-CSF tested were $2 \mathrm{ng} / \mathrm{ml}(\diamond), 0.2 \mathrm{ng} / \mathrm{ml} \mathrm{( \square ),}$ $0.02 \mathrm{ng} / \mathrm{ml}(\Delta)$, and none (o). Each point is the mean of triplicate determinations. The values obtained with neutrophils treated with $\mathrm{rH}$ GM-CSF at $2 \mathrm{ng} / \mathrm{ml}$ were significantly different from those obtained with neutrophils treated with medium by $\chi^{2}$ analysis $(P$ $<0.001$ ).

Effect of $r H$ GM-CSF on neutrophil degranulation. To test the effect of rH GM-CSF on neutrophil degranulation, a stimulus which is a complete secretagogue for neutrophils was used and the amount of lysozyme released into the supernatant was measured. rH GM-CSF increased FMLP-stimulated degranulation of Cytochalasin B-treated neutrophils (Table I). Semi-purified CSF- $\alpha$ had similar effects as did $F\left(a b^{\prime}\right)_{2}$ fragments of the MAb WEM-G11, which was used as a positive control (15). Neither rH GM-CSF nor CSF- $\alpha$ stimulated lysozyme secretion by themselves (absence of FMLP). Similarly, no lysozyme secretion was detected if neutrophils were not treated with Cytochalasin B or if neutrophils were treated with LPS at $1 \mathrm{ng} / \mathrm{ml}$. In two other experiments $\mathrm{rH}$ GM-CSF was found to enhance lysozyme secretion from neutrophils treated with Cytochalasin B and stimulated by $10^{-8} \mathrm{M}$ FMLP in a dose-dependent manner (Table II).

Stimulation of neutrophil-mediated iodination by $r H$ GM$C S F$. In the absence of a stimulus no iodination by neutrophils takes place during an incubation period of $1 \mathrm{~h}$. The addition of rH GM-CSF alone induced a very low degree of iodination by neutrophils (Table III). By contrast, and as described previously (29), rH GM-CSF strongly stimulated iodination by eosinophils (data not shown). Similarly to rH GM-CSF, zymosan stimulated very little neutrophil-mediated iodination by itself. However, the addition of rH GM-CSF and zymosan appeared to have a synergistic effect, enhancing iodination by neutrophils to levels significantly greater $(P<0.001)$ than those obtained by either stimulus alone.

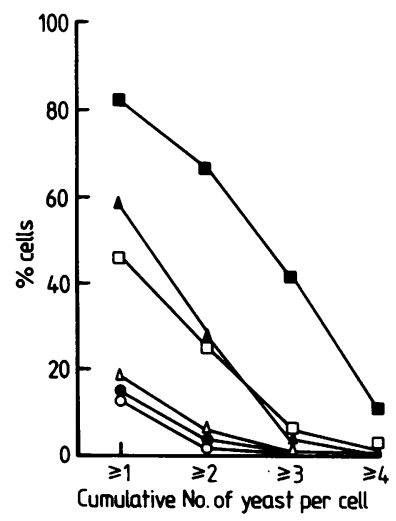

Figure 4. Stimulation by rH GMCSF of eosinophil-mediated phagocytosis of yeast organisms opsonized with different concentrations of human serum. Values obtained in the presence of $2 \mathrm{ng} / \mathrm{ml}$ of $\mathrm{rH}$ GM-CSF are shown as closed symbols, and those obtained in the presence of medium were shown as open symbols. The serum concentrations used were $2.5 \%(\square), 1.2 \%$ $(\Delta)$, and none (o). Each point is the mean of triplicate determinations. The values obtained with eosinophils treated with $\mathrm{rH} \mathrm{GM-CSF}$ were significantly different from those obtained with eosinophils treated with medium by $\chi^{2}$ analysis $(P<0.001)$ at $2.5 \%$ and $1.2 \%$ serum concentrations.
Table I. $r H$ GM-CSF Enhances Lysozyme Secretion from Cytochalasin B-treated Human Neutrophils Stimulated with FMLP

\begin{tabular}{|c|c|c|c|c|}
\hline \multirow[b]{3}{*}{ Stimulus:FMLP } & \multicolumn{4}{|l|}{ Lysozyme* } \\
\hline & \multicolumn{4}{|c|}{ Preincubation with: } \\
\hline & $\begin{array}{l}\mathrm{rH} \mathrm{GM}-\mathrm{CSF} \\
(2 \mathrm{ng} / \mathrm{ml})\end{array}$ & CSF- $\alpha(1: 100)$ & $\begin{array}{l}\text { WEM-G11 } \\
\text { F(ab') } \\
(60 \mathrm{ng} / \mathrm{ml})\end{array}$ & Medium \\
\hline $10^{-7} \mathrm{M}$ & $340 \pm 9 \ddagger$ & $193 \pm 3$ & $205 \pm 9$ & $105 \pm 10$ \\
\hline $10^{-8} \mathrm{M}$ & $245 \pm 10$ & $145 \pm 0$ & $167 \pm 6$ & $60 \pm 0$ \\
\hline None & $0 \pm 0$ & $0 \pm 0$ & $20 \pm 10$ & $0 \pm 0$ \\
\hline
\end{tabular}

* Units of measure, $\mathrm{U} / \mathrm{ml}$ per minute per $10^{6}$ cells.

¥ Arithmetic means of triplicate determinations followed by $1 \mathrm{SD}$. Maximum, $372 \pm 12 \mathrm{U} / \mathrm{ml}$ per minute per $10^{6}$ cells.

Purified neutrophils $\left(5 \times 10^{6} / \mathrm{ml}\right)$, pretreated with $5 \mu \mathrm{g} / \mathrm{ml}$ cytochalasin $B$ for $15 \mathrm{~min}$ at $37^{\circ} \mathrm{C}$ were incubated with different stimuli for 30 min at $37^{\circ} \mathrm{C}$. To these mixtures different concentrations of FMLP were added and the cells were incubated a further $30 \mathrm{~min}$ at $37^{\circ} \mathrm{C}$. After incubation the cells were centrifuged and the released lysozyme was assayed against Micrococcus Lysodeikticus. The O.D. at $450 \mathrm{~nm}$ was measured in triplicate at $10 \mathrm{~s}$ intervals for $3 \mathrm{~min}$ and the amount of lysozyme released was calculated from a standard curve generated by egg white lysozyme. Maximum values were obtained by using supernatants from neutrophils lysed with Triton X-100.

Stimulation of neutrophil superoxide production by rH GMCSF. A titration of rH GM-CSF showed that neutrophils responded with an increased production of $\mathrm{O}_{2}^{-}$upon stimulation with FMLP as judged by the increased reduction of cytochromeC observed. Fig. 5 shows one representative experiment out of six performed. Very little reduction of cytochrome-C was detected with neutrophils preincubated with $\mathrm{rH}$ GM-CSF without the addition of FMLP. LPS at $1 \mathrm{ng} / \mathrm{ml}$ did not enhance the neutrophil response to FMLP. That rH GM-CSF but not LPS was responsible for the stimulatory effect on neutrophils was further demonstrated by one experiment in which preincubation of $\mathrm{rH}$ GM-CSF with polymyxin B did not reduce its stimulatory activity.

Effect of $r H$ GM-CSF on neutrophil adherence. The effect of rH GM-CSF on the ability of neutrophils to adhere to human endothelial cells from umbilical cord veins and plastic surfaces was measured, as these phenomena appear to be the earliest steps leading to neutrophil migration into inflammatory sites. rH GM-CSF was unable to stimulate neutrophil adherence to

Table II. Enhancement of Lysozyme Secretion by Cytochalasin B-treated, FMLP-stimulated Neutrophils by rH GM-CSF at Different Concentrations

\begin{tabular}{|c|c|c|c|c|}
\hline \multirow[b]{2}{*}{ Experiment } & \multicolumn{4}{|l|}{ Lysozyme* } \\
\hline & $\begin{array}{l}{[\mathrm{rH} \text { GM-CSF], }} \\
2 \mathrm{ng} / \mathrm{ml}\end{array}$ & $\begin{array}{l}\text { [rH GM-CSF], } \\
0.2 \mathrm{ng} / \mathrm{ml}\end{array}$ & $\begin{array}{l}\text { [rH GM-CSF], } \\
0.02 \mathrm{ng} / \mathrm{ml}\end{array}$ & None \\
\hline 1 & $230 \pm 9 \ddagger$ & $225 \pm 4$ & $115 \pm 3$ & $70 \pm 3$ \\
\hline 2 & $207 \pm 6$ & $200 \pm 4$ & $127 \pm 0$ & $105 \pm 6$ \\
\hline
\end{tabular}

* Units of measure, $\mathrm{U} / \mathrm{ml}$ per minute per $10^{6}$ cells.

¥ Arithmetic means of triplicate determinations followed by 1 SD. Maximum for experiment 1, 268 \pm 12 , and for experiment 2, 248 \pm 10 . Details are as for Table I. Neutrophils were stimulated with FMLP at $10^{-8} \mathrm{M}$. 
Table III. rH GM-CSF Enhances Iodination

by Neutrophils Stimulated with Zymosan

\begin{tabular}{lllll}
\hline lodination & rH GM-CSF & Zymosan & $\begin{array}{l}\text { rH GM-CSF } \\
+ \text { zymosan }\end{array}$ & $P^{*}$ \\
\hline $\begin{array}{c}\text { nmol/h per } \\
10^{7} \text { cells }\end{array}$ & $0.10 \pm 0.04(5)$ & $0.44 \pm 0.19(4)$ & $5.98 \pm 0.84(3)$ & $<0.001$ \\
Percent & $0.64 \pm 0.26(5)$ & $2.65 \pm 1.2(4)$ & $38.4 \pm 5.50(3)$ & $<0.001$ \\
\hline
\end{tabular}

The reaction mixture contained $4 \times 10^{-3} \mathrm{M}$ sodium phosphate buffer, $\mathrm{pH} 7.4$, $0.128 \mathrm{M} \mathrm{NaCl}, 1.2 \times 10^{-2} \mathrm{M} \mathrm{KCl}, 10^{-3} \mathrm{CaCl}_{2}, 2 \times 10^{-3} \mathrm{MgCl}_{2}, 8 \times 10^{-6} \mathrm{NaI}(4$ nmol; $\left.0.05 \mu \mathrm{Ci}^{125} \mathrm{I}\right), 2 \times 10^{-3} \mathrm{M}$ glucose, $0.25 \mathrm{mg}$ albumin, $2.5 \times 10^{6}$ neutrophils, and $2 \mathrm{ng} / \mathrm{ml} \mathrm{rH} \mathrm{GM-CSF,} 0.5 \mathrm{mg}$ zymosan, or both. The final volume was $0.5 \mathrm{ml}$ and the incubation was for $1 \mathrm{~h}$. The data are expressed as the mean $\pm \mathrm{SE}$ of $(n)$ experiments.

* $P$ value for the difference between zymosan and $\mathrm{rH}$ GM-CSF + zymosan. ¥ Percent iodide converted to a TCA-precipitable form.

endothelial cells (Fig. $6 \mathrm{~A}$ ). This was in contrast to the effects of PMA, and of rH-TNF $\alpha$, which increased neutrophil adherence to endothelial cells in a dose-dependent manner (Fig. 6 B). LPS at $1 \mathrm{ng} / \mathrm{ml}$ was also a strong stimulus for neutrophil adherence (not shown).

rH GM-CSF was also a very poor stimulus at promoting adherence of neutrophils to plastic (Fig. 7). In six individuals, the mean adherence in the absence of any stimulus (control) was $4.3 \pm 2.2$ (percentage $\pm S E$ ). The addition of $r H$ GM-CSF into the reaction increased adherence to $6.4 \pm 2.5$ (not significant). By contrast, rH TNF stimulated adherence by $18.9 \pm 4.2$ (different from control, $P<0.001$ ). In two individuals, however, neutrophils adhered to a relatively larger extent in the absence of stimulus, and in one of these the adherence could be increased by the addition of rH GM-CSF. PMA, used as a positive control, increased adherence to $50.7 \pm 9.6(n=8$, different from control, $P<0.001$ ).

Regulation of expression of granulocyte functional antigens by rH GM-CSF. rH GM-CSF was found (Fig. 8) to enhance the expression of GFA-1, GFA-2, and Mol as measured by the binding of FITC-labeled MAb WEM-G1, WEM-G 11 F $\left(a b^{\prime}\right)_{2}$ and anti-Mol to these antigens. This assay, monitored by flow cytometry, showed that the mean and median values obtained with these MAb increased when neutrophils were incubated with rH GM-CSF. Thus, the mean fluorescence values obtained with these MAb increased by $40 \%$ (range, $20-77 \%$ ) with WEM-G1, by $38 \%$ (range, $11-59 \%$ ) with WEM-G11 $\mathrm{F}\left(\mathrm{ab}^{\prime}\right)_{2}$, and by $81 \%$ (range, 52-119\%) with anti-Mol upon stimulation of neutrophils with $2 \mathrm{ng} / \mathrm{ml}$ of $\mathrm{rH}$ GM-CSF. The increase in the binding of MAb was rapid (evident at $10 \mathrm{~min}$ ) and appeared to reach a

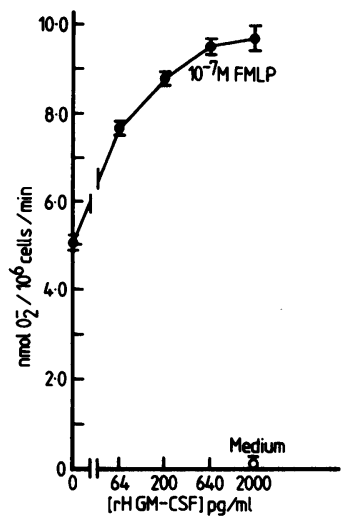

Figure 5. Effect of rH GM-CSF on the superoxide anion production of neutrophils upon stimulation with FMLP $10^{-7} \mathrm{M}(\bullet)$ or medium (0). Each point is the mean of triplicate determinations. The bars show the standard error of the mean.
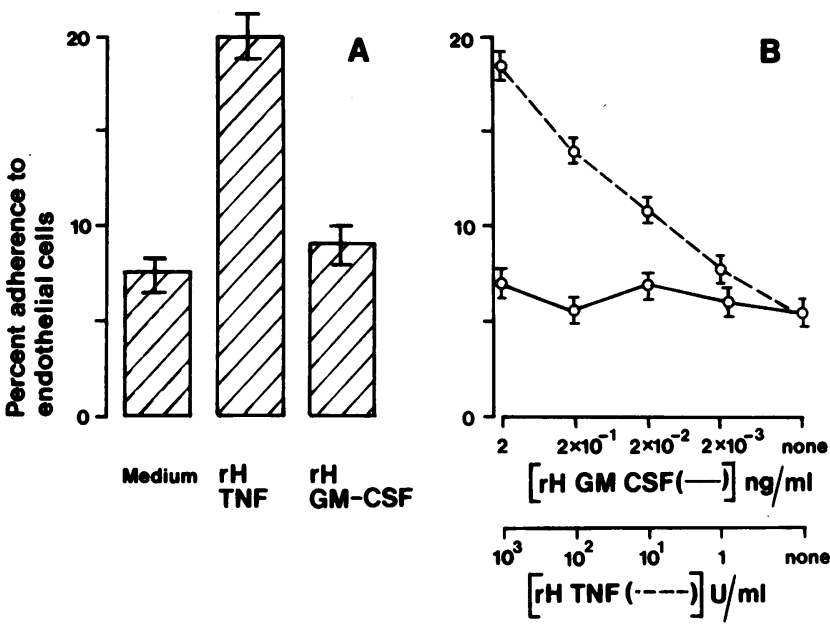

Figure 6. Adherence of neutrophils to endothelial cells. (A) Mean adherence $\pm S E$ of neutrophils from five different individuals in the presence of medium, rH GM-CSF $(2 \mathrm{ng} / \mathrm{ml})$, or $\mathrm{rH} \mathrm{TNF}-\alpha\left(10^{3} \mathrm{U} / \mathrm{ml}\right)$. (B) Dose response of neutrophils from one individual in the presence of different concentrations of rH GM-CSF (solid line) and rH TNF (dashed line). Each point is the mean of duplicate determinations. In this experiment $10 \mathrm{ng} / \mathrm{ml}$ PMA induced $75.9 \%$ adherence.

plateau at $1 \mathrm{~h}$ of incubation at $37^{\circ} \mathrm{C}$ (data not shown). In contrast, very little or no increase was seen in the binding of MAb anti$\beta_{2} \mathrm{~m}$, or the isotype matched but nonbinding controls $\mathrm{K} 7$ or PB10.

The selective upregulation of functional antigens was also demonstrable on human eosinophils. Thus, rH GM-CSF enhanced the expression of GFA-1 by $58 \%$ and of Mol by $68 \%$ but no increase was seen in the binding of anti- $\beta_{2} \mathrm{~m}, \mathrm{~K} 7$, or PB10. LPS at a concentration of $3 \mathrm{ng} / \mathrm{ml}$ had no effect on the upregulation of neutrophil and eosinophil functional antigens.

Effect of rH GM-CSF on granulocyte morphology. Upon incubation with $\mathrm{rH} \mathrm{GM}-\mathrm{CSF}$ at $37^{\circ} \mathrm{C}$ a change in the shape of granulocytes was noted. The neutrophils appeared irregular in shape and elongated and eosinophils assumed a triangular shape with the granules concentrated near the base. These changes were interpreted as polarization. The change in shape in neutrophils was similar to that seen with FMLP and other stimuli. A titration of $\mathrm{rH} \mathrm{GM}-\mathrm{CSF}$ showed that most neutrophils were polarized at $15 \mathrm{~min}$ at $\mathrm{rH}$ GM-CSF concentrations of $0.2 \mathrm{ng} /$ $\mathrm{ml}$ and above (Fig. $9 \mathrm{~A}$ ). Eosinophils and neutrophils showed a

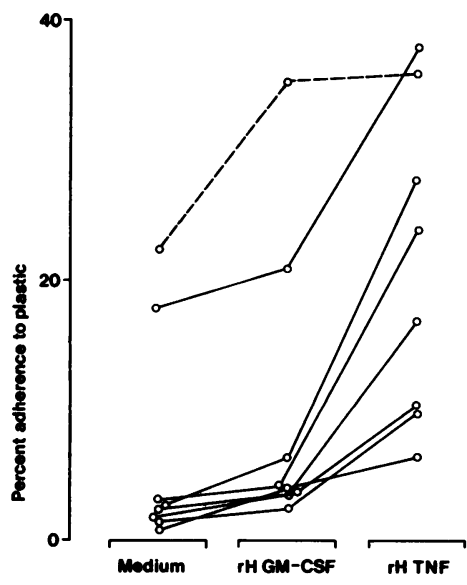

Figure 7. Adherence of neutrophils from eight individuals to plastic in the presence of medium, rH GMCSF $(2 \mathrm{ng} / \mathrm{ml})$, and $\mathrm{rH}$ TNF- $\alpha\left(10^{3} \mathrm{U} / \mathrm{ml}\right)$. Each point is the mean of quadruplicate determinations. The lines join the values obtained with neutrophils from the same individual. The broken line shows the values obtained with neutrophils from a high responder individual. 


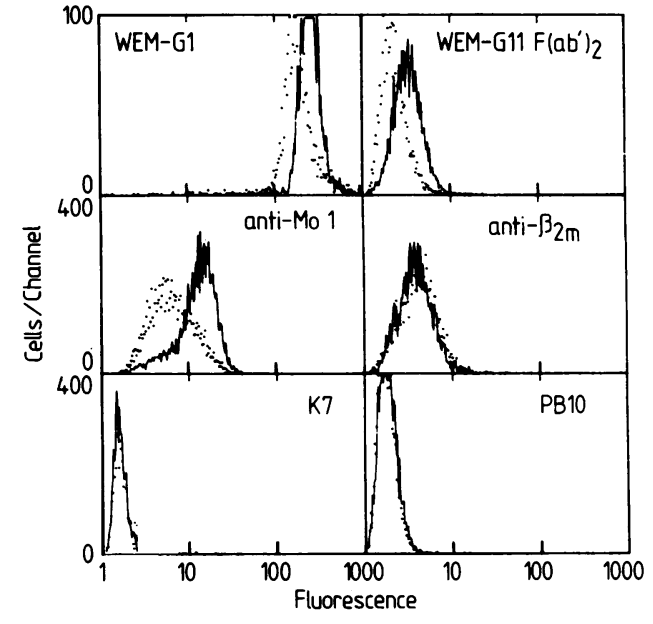

Figure 8. Fluorescence-activated cell sorter (FACS) profiles of the binding of MAb WEM-G1, WEM-G11 F( $\left(\mathrm{ab}^{\prime}\right)_{2}$, anti-Mol, anti- $\beta_{2}, \mathrm{~K} 7$, and $\mathrm{PB} 10$ to human neutrophils preincubated with medium (dotted line) or $\mathrm{rH} \mathrm{GM-CSF}$ (continuous line) at $2 \mathrm{ng} / \mathrm{ml}$. The increase in binding obtained with MAb WEM-G1, WEM-G11, F(ab') $)_{2}$, and antiMol was significantly higher $(P<0.001)$ than the coefficient of variation of the FACS $(<3 \%)$.

similar dose response with rH GM-CSF. Four other experiments gave similar results but with up to a fourfold variation in the dose of $\mathrm{rH} \mathrm{GM-CSF}$ required to induce maximal responsiveness depending on the individual tested. The polarization of neutrophils by rH GM-CSF was seen within 5 min (Fig. 9 B). The changes observed by light microscopy were also reflected by an increase in the $0^{\circ}$ light scatter of neutrophils as measured by flow cytometry (Fig. $9 \mathrm{~B}$ ). The $0^{\circ}$ light scatter also reflected the dose response relationship (data not shown).
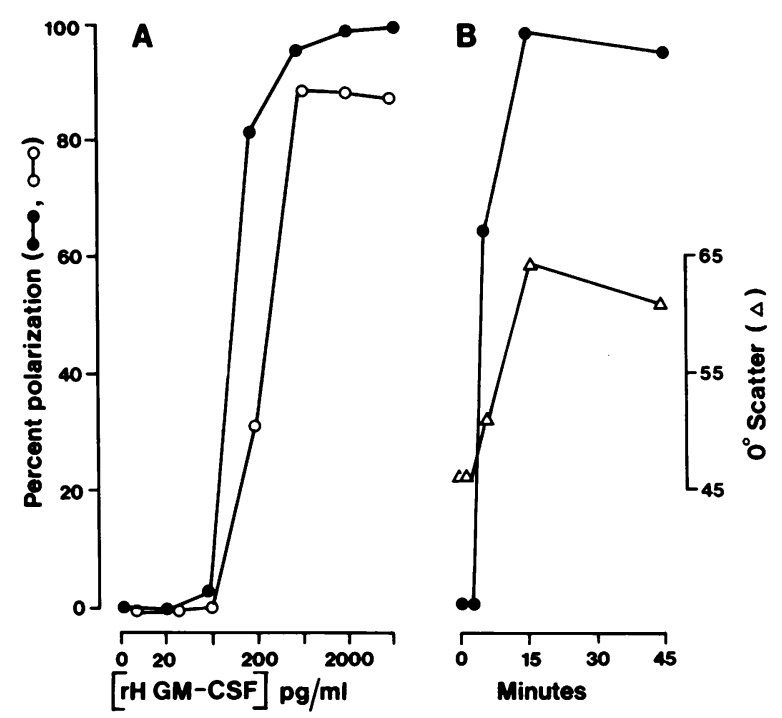

Figure 9. Morphological changes induced on human neutrophils (•) and eosinophils (o) by rH GM-CSF at 15 min of incubation. (A) Dose response of $\mathrm{rH}$ GM-CSF expressed as percent polarized cells after visual examination. (B) Time course of the effect of rH GM-CSF ( $2 \mathrm{ng} /$ $\mathrm{ml}$ ) on neutrophils expressed as percent polarized cells based on visual examination (๑) and as mean channel number in the $0^{\circ}$ scatter measured by flow cytometry $(\Delta)$. Each point is the mean of duplicate determinations.
Effect of rH GM-CSF on the survival of mature neutrophils and eosinophils. rH GM-CSF increased the survival of mature neutrophils as well as eosinophils in vitro. In four experiments performed, determinations of the time points at which $50 \%$ of plated cells were still alive revealed that $\mathrm{rH}$ GM-CSF significantly enhanced the median survival in vitro of eosinophils from $30 \mathrm{~h}$ (medium control) to $39 \mathrm{~h}(P<0.005)$, and that of neutrophils from $22 \mathrm{~h}$ (medium control) to $28 \mathrm{~h}(P<0.0025)$. In each case a titration of $\mathrm{rH}$ GM-CSF was carried out. A representative experiment out of eight performed is shown in Fig. 10 where neutrophils were examined after $28 \mathrm{~h}$ and eosinophils were examined after $31 \mathrm{~h}$ of incubation. rH GM-CSF at a concentration as low as $5 \mathrm{pg} / \mathrm{ml}$ was enough to support maximum levels of survival of both neutrophils and eosinophils. As the rH GM-CSF was diluted out, the number of viable cells rapidly decreased. The percentage of viable cells in cultures containing only medium with FCS was $\sim 25 \%$ of that seen with optimal amounts of $\mathrm{rH}$ GM-CSF at these time points.

\section{Discussion}

In this paper we definitively show that a purified recombinant human GM-CSF (rH GM-CSF) stimulates the function of mature neutrophils as well as eosinophils, enhances the expression of functional antigens, and prolongs their survival in vitro.

Previous experiments in the mouse have shown that macrophages could be stimulated by GM-CSF to kill parasites (30) and by macrophage-CSF (M-CSF) to produce plasminogen activator (31). Furthermore, both granulocyte-CSF (G-CSF) and GM-CSF purified to homogeneity were shown to activate mouse neutrophils and G-CSF also stimulated human neutrophil but not eosinophil function (3).

In the human, early experiments had strongly suggested that one of the chief effects of CSF was the activation of mature granulocytes. For example, human placental conditioned medium (HPCM), a rich source of CSF, stimulated the killing of parasites by eosinophils (32), and HPCM as well as semipurified CSF- $\alpha$ and CSF- $\beta$ enhanced the ADCC of tumor cells by human neutrophils (2). In addition, human mononuclear cell supernatants with CSF activity were found to enhance the helminthotoxic capacity of eosinophils (33) and stimulated neutrophils to kill microorganisms and tumor cells $(34,35)$. More impor-

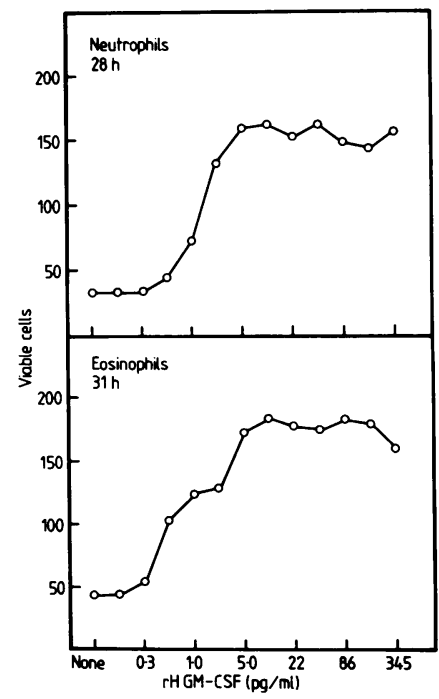

Figure 10. Stimulation by $\mathrm{rH}$ GM-CSF of the survival of mature human neutrophils and eosinophils. Purified cells were dispensed in Terasaki plates at $\sim 200$ per microwell in medium containing $10 \%$ FCS and different concentrations of $\mathrm{rH}$ GM-CSF. After the specified time the number of viable cells in each well was recorded. Each point shown is the mean of duplicate determinations. 
tantly, fractionation of these mononuclear cell supernatants showed that the fractions with CSF activity co-chromatographed with fractions showing stimulation of killing by neutrophils and eosinophils (35).

Subsequent studies showed that GM-CSF purified from Mo cells-conditioned medium inhibited the migration of human neutrophils in agarose (7), and that the purified recombinant GM-CSF molecule increased superoxide anion production by neutrophils stimulated with FMLP (36). Preliminary experiments also showed that this material enhanced the cytotoxic and phagocytic activities of neutrophils (4). In this paper we confirm some of these findings and extend these observations to show that rH GM-CSF stimulates several but not all parameters of granulocyte function and is active on eosinophils as well as on neutrophils.

The first point of interest was that $\mathrm{rH}$ GM-CSF stimulated both neutrophil and eosinophil function (Figs. 1-5, Tables IIII). This is notable since the stimulation of function in both cell types previously seen with CSF- $\alpha$ (2) can now be attributed to a single molecule. It should also be pointed out that in some assays (e.g., ADCC), the stimulation of eosinophil function was stronger than that of neutrophil function, a pattern not seen with CSF- $\alpha$ (2; and our unpublished observations). Thus, it is still possible that another stimulatory molecule was present in CSF- $\alpha$ which was responsible for the strong stimulation of neutrophil function.

A second point of interest was the enhancement of the expression of GFA-1, GFA-2, and Mo-1 but not $\beta_{2}$ m by rH GM-CSF, which suggests that CSFs, like the bacterial products LPS and FMLP (22), and the complement component C5a (37), selectively up-regulate the surface expression of functionally important molecules. In fact, the increase in binding of both radiolabeled C3bi (38) and of antibody to the complement receptor type 3 (CR3) for C3bi (39) on neutrophils incubated with Raji cell supernatants may be due to the up-regulation of this receptor (which is located on the Mol antigen) by CSF present in such supernatants. The upregulation of granulocyte functional antigens may be one important mechanism by which CSF and other factors play a role in vivo.

The stimulation of granulocytes by $\mathrm{rH}$ GM-CSF involved two types of functions. One was opsonin-dependent and encompassed ADCC (Fc-mediated) and fresh serum-dependent phagocytosis (complement-mediated). Enhancement of this type of function may be useful in vivo where activation of granulocytes by GM-CSF may not take place until granulocytes encounter the appropriate target. Although it can be argued that stimulation of this type of function is secondary to an increase in the relevant receptors (i.e. Fc, CR3) on granulocytes (Fig. 8), the magnitude of the different responses and the lack of effect of $\mathrm{rH}$ GM-CSF on adherence (see below) would suggest that this is not the only mechanism by which rH GM-CSF exerts its function. The second type of functions stimulated by CSF depends on a secondary stimulus, FMLP in the case of $\mathrm{O}_{2}^{-}$production and degranulation, and zymosan in iodination experiments. While the stimulation of these functions may reflect changes in FMLP and zymosan receptor numbers or behavior, note that the stimulation observed is much greater than that seen with maximal FMLP doses, which suggests an increased intrinsic responsiveness to this agent.

The failure of $\mathrm{rH}$ GM-CSF to enhance the adhesiveness of neutrophils to plastic or endothelial surfaces was a notable neg- ative finding, showing that the stimulation of granulocyte function by $\mathrm{rH}$ GM-CSF is selective.

The adherence of granulocytes to vascular endothelium is the initial step in the emigration of these cells into the tissues, and as such is central to the process of inflammation (40). This adherence of granulocytes to endothelium has been shown to be influenced by bacterial products and components of the complement cascade (41), platelet products (42), and more recently by $\mathrm{rH} \mathrm{TNF} \alpha$ (43). These data suggest that while GM-CSF may be of great importance in stimulating human neutrophil and eosinophil function at the site of inflammation, cell-derived products other than GM-CSF are responsible for stimulating granulocyte adherence leading to their emigration into inflammatory sites. This is an important point in future considerations involving the therapeutic administration of CSF, as it would suggest that the clinical use of CSF may be safe inasmuch as thrombotic reaction would not be predicted to occur.

Since these adhesive phenomena appear to involve the surface glycoproteins with C3bi receptor function (43), our negative findings are also important when contrasted with the results with phagocytosis also apparently dependent on the same neutrophil structure (44). This would support the notion that the stimulatory phenomena involve mechanisms äpart from up-regulation of these surface receptors.

The rapid induction of morphological changes was similar to those noted in neutrophils incubated with FMLP (45) and phorbol myristate acetate (PMA) (27), and in the latter case these changes could be correlated with superoxide release and activation of protein kinase C. FMLP was also shown to cause polarization of human neutrophils which parallelled F-actin depolymerization and redistribution (46). The polarization of neutrophils by $\mathrm{rH}$ GM-CSF could also be detected by flow cytometry as judged by the increase in forward light scatter, an increase also seen when neutrophils were stimulated with FMLP and PMA (28). Taken together, these data suggest that rH GM-CSF induces morphological changes in neutrophils also seen with other activating agents and that these may be a reflection of cytoskeleton modifications and the state of activation of the cells.

The last parameter examined of granulocyte stimulation by rH GM-CSF was the survival in vitro. CSF is known to prolong the survival of bone marrow progenitor cells (1), and mouse $M$ CSF (CSF-1) has been shown to be required for the survival of bone marrow, resident peritoneal, and cultured peritoneal exudate macrophages (47). The demonstration that rH GM-CSF can extend the survival of both human neutrophils and eosinophils is in agreement with the specificity shown in functional assays. This effect may be beneficial in vivo by giving granulocytes a longer life span to carry out their effector function.

rH GM-CSF prolonged the survival of neutrophils for $\sim 6$ $\mathrm{h}$ and that of eosinophils for $\sim 9 \mathrm{~h}$. While the in vivo relevance of this phenomenon is not yet known the prolongation of granulocyte survival in peripheral blood may account for rapid changes in blood neutrophil numbers not previously explicable by demargination or bone marrow production. The low amounts of $\mathrm{rH} \mathrm{GM-CSF}$ required to induce this phenomenon points to its possible use in therapy.

Also note, however, that CSF may be harmful if present in high concentration at sites of inflammation where it could play a role in the pathogenesis of certain diseases. Preliminary experiments have suggested that this may be the case in rheumatoid arthritis where CSF can be found in the fluid of diseased joints 
(Williamson, D. J., C. G. Begley, M. A. Vadas, and D. Metcalf, unpublished observations).

The effects of rH GM-CSF on mature cells clearly encompasses activation, enhanced antigen expression, and survival. The degree to which these three parameters are related is not yet clear and it is possible that most parameters of activation may be explicable by the effect on receptor numbers and on survival. Regardless of the exact mechanism involved, the functional effects of rH GM-CSF on mature cells is likely to be biologically significant, and one that could be exploited therapeutically. For example, CSF may be a useful adjunct in the treatment of infections as well as in the ex vivo prolongation of granulocyte survival. In addition, the effect on mature cells will have to be taken into account when these substances are administered systemically to stimulate the proliferation and differentiation of bone marrow cells.

\section{Acknowledgments}

We would like to thank Lucia Callegaro and Dora Vasiliadis for excellent technical assistance, Dr. F. Battye for assistance with the FACS, and Dr. D. Metcalf, Dr. N. Nicola, Dr. N. Hurst, and Dr. G. F. Burns for criticizing the manuscript.

This work was supported by grants from the National Health and Medical Research Council of Australia, and National Institutes of Health (United States) grant AI-21876 and AI-07763.

\section{References}

1. Metcalf, D. 1984. The hemopoietic colony-stimulating factors. Elsevier/North Holland, Amsterdam. 1-486.

2. Vadas, M. A., N. A. Nicola, and D. Metcalf. 1983. Activation of antibody-dependent cell-mediated cytotoxicity of human neutrophils and eosinophils by separate colony-stimulating factors. J. Immunol. 130:795799.

3. Lopez, A. F., N. A. Nicola, A. W. Burgess, D. Metcalf, F. L. Battye, W. Sewell, and M. A. Vadas. 1983. Activation of granulocyte cytotoxic function by purified mouse colony-stimulating factors. J. Immunol. 131:2983-2988.

4. Metcalf, D., C. G. Begley, G. R. Johnson, N. A. Nicola, M. A. Vadas, A. F. Lopez, D. J. Williamson, G. G. Wong, S. C. Clark, and E. A. Wang. 1986. Biologic properties in vitro of a recombinant human granulocyte-macrophage colony-stimulating factor. Blood. 67:37-45.

5. Nicola, N. A., D. Metcalf, G. R. Johnson, and A. W. Burgess. 1978. Preparation of colony-stimulating factors from human placental conditioned medium. Leuk. Res. 2:313-322.

6. Nicola, N. A., D. Metcalf, G. R. Johnson, and A. W. Burgess. 1979. Separation of functionally distinct human granulocyte-macrophage colony-stimulating factors. Blood. 54:614-627.

7. Gasson, J. C., R. H. Weisbart, S. E. Kaufman, S. C. Clark, R. M. Hewick, G. G. Wong, and D. W. Golde. 1984. Purified human granulocyte-macrophage colony-stimulating factor: direct action on neutrophils. Science (Wash. DC). 226:1339-1342.

8. Wong, G. G., J. S. Witek, P. A. Temple, K. M. Wilkens, A. C. Leary, D. P. Luxenberg, S. S. Jones, E. L. Brown, R. M. Kay, E. C. Orr, C. Shoemaker, D. W. Golde, R. J. Kaufman, R. M. Hewick, E. A. Wang, and S. C. Clark. 1985. Human GM-CSF. Molecular cloning of the cDNA and purification of the natural and recombinant proteins. Science (Wash. DC). 228:810-815.

9. Lee, F. T., T. Yokota, T. Otsuka, L. Gemmell, N. Larson, J. Luk, K. I. Arai, and D. Rendwick. 1985. Isolation of cDNA for a human granulocyte-macrophage colony-stimulating factor by functional expression in mammalian cells. Proc. Natl. Acad. Sci. USA. 82:43604364.
10. Lopez, A. F., C. G. Begley, D. J. Williamson, D. J. Warren, M. A. Vadas, and C. J. Sanderson. 1986. Murine eosinophil differentiation factor. An eosinophil-specific colony-stimulating factor with activity for human cells. J. Exp. Med. 163:1085-1099.

11. Vadas, M. A., J. R. David, A. E. Butterworth, N. T. Pisani, and T. A. Siongok. 1979. A new method for the purification of human eosinophils and neutrophils, and a comparison of the ability of these cells to damage schistosomula of Schistosoma mansoni. J. Immunol. 122: $1228-1236$

12. Clark, R. A., and S. J. Klebanoff. 1979. Role of the myeloperoxidase- $\mathrm{H}_{2} \mathrm{O}_{2}$ halide system in concanavalin A-induced tumor cell killing by human neutrophils. J. Immunol. 122:2605-2610.

13. Nicola, N. A., C. G. Begley, and D. Metcalf. 1985. Identification of the human analogue of a regulator that induces differentiation in murine leukaemic cells. Nature (Lond.). 314:625-628.

14. Pennica, D., G. E. Nedwin, J. S. Hayflick, P. H. Seeburg, R. Derynck, M. A. Palladino, W. J. Kohr, B. B. Aggarwal, and D. V. Eoeddel. 1984. Human tumour necrosis factor: precursor structure, expression and homology to lymphotoxin. Nature (Lond.). 312:724-729.

15. Pereira, H. A., and C. S. Hosking. 1984. The role of complement and antibody in opsonization and intracellular killing of Candida albicans. Clin. Exp. Immunol. 57:307-314.

16. Lopez, A. F., C. G. Begley, P. Andrews, A. E. Butterworth, and M. A. Vadas. 1985. Identification of a human granulocyte functional antigen (GFA-2) involved in antibody-dependent cell-mediated cytotoxicity and phagocytosis. J. Immunol. 134:3969-3977.

17. Klebanoff, S. J., and R. A. Clark. 1977. Iodination by human polymorphonuclear leukocytes: a re-evaluation. J. Lab. Clin. Med. 89: 675-686.

18. Weening, R. S., R. Weever, and D. Roos. 1975. Quantitative aspects of the production of superoxide radicals by phagocytizing human granulocytes. J. Lab. Clin. Med. 85:245-252.

19. van Gelder, B. F., and E. C. Slater. 1962. The extinction coefficient of cytochrome C. Biochim. Biophys. Acta. 58:593-595.

20. Gallin, J. T., R. A. Clark, and H. R. Kimball. 1973. Granulocyte chemotaxis: an improved in vitro assay employing ${ }^{51} \mathrm{Cr}$-labelled granulocytes. J. Immunol. 110:233-240.

21. Wall, R. T., L. A. Harker, L. J. Quadracci, and G. E. Striker. 1978. Factors influencing endothelial cell proliferation in vitro. J. Cell. Physiol. 96:203-213.

22. Vadas, M. A., A. F. Lopez, and D. J. Williamson. 1985. Selective enhancement of the expression of granulocyte-functional-antigens 1 and 2 on human neutrophils. Proc. Natl. Acad. Sci. USA. 82:2503-2507.

23. Goding, J. 1976. Conjugation of antibodies with fluorochromes: modification to the standard methods. J. Immunol. Meth. 13:215-226.

24. Lopez, A. F., and M. A. Vadas. 1984. Stimulation of human granulocyte function by monoclonal antibody WEM-G1. Proc. Natl. Acad. Sci. USA. 81:1818-1821.

25. Arnaout, M. A., R. F. Todd III, N. Dana, J. Melamed, S. F. Schlossman, and H. R. Colten. 1983. Inhibition of phagocytosis of complement C3- or IgG-coated particles and C3bi binding by monoclonal antibodies to a monocyte-granulocyte membrane glycoprotein (Mo-1). J. Clin. Invest. 72:171-179.

26. Wright, S. D., P. E. Rao, W. C. Van Voorhis, L. S. Craigmyle, K. Iida, M. A. Talle, E. F. Westberg, G. Goldstein, and S. Silverstein. 1983. Identification of the $\mathrm{C} 3 \mathrm{bi}$ receptor of human monocytes and macrophages by using monoclonal antibodies. Proc. Natl. Acad. Sci. USA. 80:5699-5703.

27. Robinson, J. M., J. A. Badway, M. L. Karnovsky, and M. J. Karnovsky. 1985. Release of superoxide and change in morphology by neutrophils in response to phorbol esters: antagonism by inhibitors of calcium binding proteins. J. Cell. Biol. 101:1052-1058.

28. Fletcher, M. P., and B. E. Seligmann. 1985. Monitoring human neutrophil granule secretion by flow cytometry: secretion and membrane potential changes assessed by light scatter and a fluorescent probe of membrane potential. J. Leuk. Biol. 37:431-447.

29. Vadas, M. A., G. Varigos, N. A. Nicola, S. Pincus, A. Dessein, 
D. Metcalf, and F. L. Battye. 1983. Eosinophil activation by colonystimulating factor in man: metabolic effects and analysis by flow cytometry. Blood. 61:1232-1241.

30. Handman, E., and A. W. Burgess. 1979. Stimulation by granulocyte-macrophage colony-stimulating factor of Leishmania tropica killing by macrophages. J. Immunol. 122:1134-1137.

31. Hamilton, J. A., E. R. Stanley, A. W. Burgess, and R. K. Shadduck. 1980. Stimulation of macrophage plasminogen activator activity by colony-stimulating factors. J. Cell Physiol. 103:435-445.

32. Dessein, A. J., M. A. Vadas, N. A. Nicola, D. Metcalf, and J. R. David. 1982. Enhancement of human blood eosinophil cytotoxicity by semipurified eosinophil colony stimulating factor(s). J. Exp. Med. 156: 90-103.

33. Veith, M. C., and A. E. Butterworth. 1983. Enhancement of human eosinophil-mediated killing of Schistosoma mansoni larvae by mononuclear cell products in vitro. J. Exp. Med. 157:1828-1843.

34. Cross, A. S., and G. H. Lowell. 1978. Stimulation of polymorphonuclear leukocyte bactericidal activity by supernatants of activated human mononuclear cells. Infec. Immun. 78:502-507.

35. Vadas, M. A., N. A. Nicola, A. F. Lopez, D. Metcalf, G. R. Johnson, and A. Pereira. 1984. Mononuclear cell-mediated enhancement of granulocyte function in man. J. Immunol. 133:202-207.

36. Weisbart, R. H., D. W. Golde, S. C. Clark, G. G. Wong, and J. C. Gasson. 1985. Human granulocyte-macrophage colony-stimulating factor is a neutrophil activator. Nature (Lond.). 314:361-363.

37. Yancey, K. B., J. O'Shea, T. Crushed, E. Brown, T. Takahashi, M. M. Frank, and T. J. Lawley. 1985. Human C5a modulates monocyte Fc and C3 receptor expression. J. Immunol. 135:465-470.

38. Berger, M., and A. S. Cross. 1984. Lymphoblastoid cell supernatants increase expression of $\mathrm{C} 3 \mathrm{~b}$ receptors on human polymorphonuclear leukocytes: direct binding studies with ${ }^{125} \mathrm{I}-\mathrm{C} 3 \mathrm{~b}$. Immunology. 51:431-439.

39. Berger, M., J. O'Shea, A. S. Cross, T. M. Folks, T. M. Chused, E. J. Brown, and M. M. Frank. 1984. Human neutrophils increase expression of $\mathrm{C} 3 \mathrm{bi}$ as well as $\mathrm{C} 3 \mathrm{~b}$ receptors upon activation. J. Clin. Invest. 74:1566-1571.

40. Harlan, J. M. 1985. Leukocyte-endothelial interactions. Blood. 65:513-525.

41. Tonnesen, M. G., L. A. Smedley, and P. M. Henson. 1984. Neutrophil-endothelial cell interactions. Modulation of neutrophil adhesiveness induced by complement fragments $C_{5 a}$ and $C_{5 a}$ des arg and formyl-methionyl-leucyl-phenylalanine in vitro. J. Clin. Invest. 74:15811592.

42. Boogaerts, M., O. Yamada, H. Jacob, and C. Moldow. 1982. Enhancement of granulocyte-endothelial cell adherence and granulocyteinduced cytotoxicity by platelet release products. Proc. Natl. Acad. Sci. USA. 79:7019-7023.

43. Gamble, J. R., J. M. Harlan, S. J. Klebanoff, and M. A. Vadas. 1985. Stimulation of the adherence of neutrophils to umbilican vein endothelium by human recombinant tumor necrosis factor. Proc. Natl. Acad. Sci. USA. 82:8667-8671.

44. Ross, G. D., R. A. Thompson, M. J. Walport, T. A. Springer, J. V. Watson, R. H. R. Ward, J. Lida, S. L. Newman, R. A. Harrison, and P. L. Lachman. 1985. Characterization of patients with an increased susceptibility to bacterial infections and a genetic deficiency of leukocyte membrane complement receptor type 3 and the related membrane antigen LFA-1. Blood. 66:882-890.

45. Guli, I., and R. Snyderman. 1984. Rapid changes in light scattering from human polymorphonuclear leukocytes exposed to chemoattractants. Discrete responses correlated with chemotactic and secretory functions. J. Clin. Invest. 73:1408-1417.

46. Howard, T. O., and C. O. Oresajo. 1985. The kinetics of chemotactic peptide-induced change in F-actin content, F-actin distribution, and the shape of neutrophils. J. Cell. Biol. 101:1078-1085.

47. Tushinski, R. J., I. T. Oliver, L. J. Guilbert, P. W. Tyman, J. R. Warmer, and E. R. Stanley. 1982. Survival of mononuclear phagocytes depends on a lineage-specific growth factor that the differentiated cells selectively destroy. Cell. 28:71-81. 